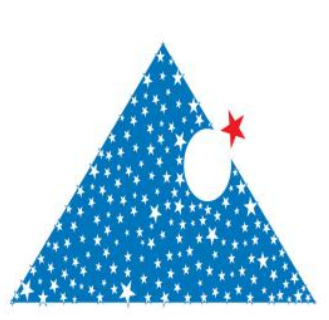

www.dergipark.gov.tr

ISSN:2148-3736

El-Cezerî Fen ve Mühendislik Dergisi

Cilt: 5, No: 1, 2018 (176-181)

El-Cezerî Journal of Science and

Engineering

Vol: 5, No: 1, $2018(176-181)$

\title{
ECJSE
}

Research Paper / Makale

\section{Dynamic Analysis of Flexible Structures Under The Influence of Moving Multiple Vehicles}

\author{
${\text { Mehmet Akif KOÇ }{ }^{1} \text {, İsmail ESEN }}^{2}$,Mustafa EROĞLU ${ }^{1}$, Yusuf ÇAY ${ }^{1}$, Ömer ÇERLEK $^{1}$ \\ ${ }^{1}$ Sakarya University, Mechanical Engineering, 54187, Sakarya, Turkey \\ ${ }^{2}$ Karabuk University, Mechanical Engineering, 78050, Karabuk, Turkey \\ e-mail:makoc@sakarya.edu.tr (corresponding author)
}

\begin{abstract}
In this study, the parameters affecting the dynamic behavior of flexible structures under the influence of multiple vehicle passages are examined in detail. The flexible structure considered in the study is considered as a bridge girder with simple supported boundary conditions which modelled according to Euler-Bernoulli thin beam theory. The equations of motion of the bridge beam in contact with the vehicle passing over the bridge were obtained by using the Lagrange equation after the kinetic and potential energies of the system were obtained. The second-order differential equations representing the motion of the system are transformed from the first-order state space matrix representation to the first-order state using the state variables specified in the study. The system of differential equations is then solved with high accuracy using a special program prepared in the MATLAB commercial software using the Runge-Kutta algorithm from the fourth degree in the time domain.
\end{abstract}

Keywords: Flexible structures, moving vehicles, simple supported beam, Lagrange equations.

\section{Esnek Yapıların Çoklu Taşıt Hareketi Etkisi Altında Dinamik Analizi}

\begin{abstract}
Özet: Bu çalışmada, esnek yapılardan çoklu taşıt geçmesi durumunda dinamik davranışa etki eden parametreler detaylı şekilde incelenmiştir. Çalışmada esnek yapı olarak; Euler-Bernoulli ince kiriş teorisine göre modellenen basit mesnetli köprü kirişi göz önüne alınmıştır. Köprü kirişi ile üzerinden geçen taşıtların temasıyla oluşan hareket denklemleri; sistemin kinetik ve potansiyel enerjisi çıkarıldıktan sonra Lagrange denklemi kullanılarak elde edilmiştir. Sistemin hareketini ifade eden ikinci dereceden diferansiyel denklemler çalışmada belirtilen durum değişkenlerini kullanarak; birinci derece durum uzay formuna dönüştürülmüştür. Diferansiyel denklem sistemi; zamana göre dördüncü dereceden Runge-Kutta algoritması ile MATLAB ticari yazılımında hazırlanan program kullanılarak yüksek hassasiyetle çözülmüştür.
\end{abstract}

Anahtar kelimeler: Esnek yapılar, hareket eden taşıtlar, basit mesnetli kiriş, Lagrange denklemleri

\section{Introduction}

Dynamic behaviour of the structures under the influence of moving loads has been widely discussed in the literature as an important topic of interest. The studies [1] in which analytical solutions of various moving load problems are given are significant works on this subject. Neglecting the damping effects for a mass moving with a constant velocity on a simply supported beam, [2] investigated the subject and proposed some analytical solution methods. Considering the effect of the mass, [3] investigated dynamic behaviour of the different beams under accelerating mass influence. Due to the complexity of the modelling, analytic solutions to the moving mass problems have stayed insufficient. Instead, studies using the finite element model (FEM) approach proposed

\footnotetext{
How to cite this article

Koç, M.A., Esen, İ., Eroğlu, M., Çay, Y., Çerlek, Ö.,"Dynamic Analysis of Flexible Structures Under The Influence of Moving Multiple Vehicles” ElCezerî Journal of Science and Engineering, 2018, 5(1); 176-181. 
by [4] can be more useful in order to get more accurate solution results without neglecting the inertia and damping effects by modelling the moving mass as a time-dependent moving finite element in the finite element model of the entire system. Moving mass and structure interaction is also an important study subject in military applications of the mechanics, and in some studies [5] one can found some FEM and heuristic methods for determining muzzle displacements resulting from projectile and gun barrel interaction by considering the Coriolis, centripetal and inertia effects of the high-speed moving projectile inside the gun barrel. One of the essential field of application of moving load problems is the vehicle bridge interaction (VBI) problem, and in this respect [6] have presented a multi-axle vehicle bridge interaction model considering bridge dynamics and neglecting the effect of the interaction on vehicle components. For railroad design and other high speed infrastructure construction the effect of the moving mass is also another application field, thus $[7,8]$ investigated the subject in terms of bridge dynamics. There are a number of studies on train-truck interaction problem by using the finite element adaptation, and the studies $[9,10]$ have suggested some solutions of train-truck interaction using FEM. For predicting vehicle induced local responses of a skewed girder bridge [11], and for impact coefficient of mid-span continuous beam bridges interaction due to passage of heavy duty trucks and trains over flexible structures such as bridges [12] have investigated the interaction of heavy-vehicles with structures. Using a half car model, [13] has studied the passenger comfort considering a vehicle moving on a flexible structure with constant velocities. Due to the recent trend in transportation, the other interaction subjects have become important, for example, [14] has presented a vehicle-track-bridge interaction element considering vehicle's pitching effect.

\section{Method}

In the formulation for the VBI analysis following assumptions will be adopted:

- $\quad$ The bridge is modelled as a simple supported beam based on Euler-Bernoulli theory.

- $\quad$ The vehicle was modelled four and six DOF as lumped parameter.

- It was accepted that one or multiple cars are moving on the bridge with constant velocity v.

- The car's wheels are always in contact with the bridge. There are not any jumping involved.

With these assumptions, the kinetic and potential energy of the vehicle-bridge-passenger interaction, as shown in Fig. 1a, is expressed as follows respectively:

$$
E_{k}=\frac{1}{2}\left(\int_{0}^{L} \mu\left[\dot{w}_{b}^{2}(x, t)+\left(m_{1} \dot{y}_{1}^{2}+m_{2} \dot{y}_{2}^{2}\right)\right]\right),
$$

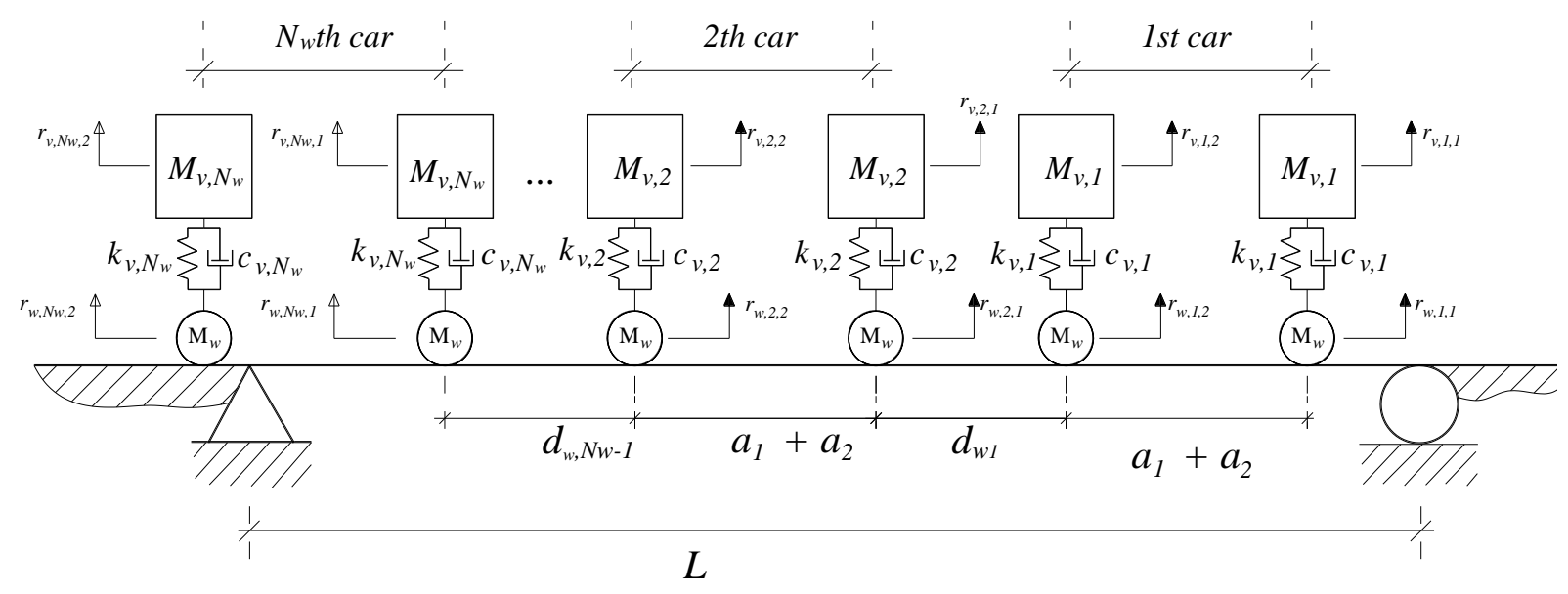

Fig. 1. Multiple vehicle and bridge interaction model used in this study. 


$$
\mathrm{E}_{p}=\frac{1}{2}\left(\int_{0}^{L} E I\left[w_{b}^{\prime \prime 2}(x, t)+\left(k_{1}\left(y_{1}-w_{b}(x, t)\right)^{2}+k_{2}\left(y_{2}-y_{1}\right)^{2}\right)\right]\right),
$$

Approaches, such as the principle of virtual work, Hamilton's principle, and D'Alembert's principle can be used for the equation of motion of the system, as shown in Fig. 1. This study uses Lagrange's equations, formed using the kinetic energy and potential energy equations of the vehicle-bridge integrated system, and the mode expansion method. The Galerkin equation for the deflection $w_{b}(x, t)$ of any point $x$ on the beam at time $t$ is expressed as follows:

$$
w_{b}(x, t)=\sum_{i=1}^{n} \varphi_{i}(x) \eta_{b i}(t)
$$

Rayleigh dissipation function for the vehicle-bridge integrated system is expressed as follows:

$$
\mathrm{D}=\frac{1}{2}\left[\int_{0}^{L} c \dot{w}_{b}^{2} d x+c_{1}\left(\dot{y}_{1}-\dot{w}_{b}(x, t)\right)^{2}+c_{2}\left(\dot{y}_{2}-\dot{y}_{1}\right)^{2}\right],
$$

In Eq. (3), c is the equivalent damping function for bridge beam. In addition, the Lagrange equation ( $L=E_{k}-E_{p}$ ) of the system is equal to the difference between the kinetic energy and the potential energy. If the Lagrange equation is rearranged for six independent coordinates, the following is obtained:

$$
\begin{gathered}
\frac{\mathrm{d}}{\mathrm{d} t}\left(\frac{\partial L}{\partial \dot{p}_{k}(t)}\right)-\frac{\partial L}{\partial p_{k}(t)}+\frac{\partial R}{\partial \dot{p}_{k}(t)}=0, k=1,2 . \\
\frac{\mathrm{d}}{\mathrm{d} t}\left(\frac{\partial L}{\partial \dot{\eta}_{i}(t)}\right)-\frac{\partial L}{\partial \eta_{i}(t)}+\frac{\partial D}{\partial \dot{\eta}_{i}(t)}=Q_{i}, \quad \mathrm{i}=1,2,3,4,
\end{gathered}
$$

Solution steps of multiple cars:

1. Define the parameters $N_{w}, d_{w}, a_{i}(i=1,2)$, see Fig. 1 .

2. For the parameters make a vector for each axle. Remember for $N_{w}$ cars there should be $2 N_{w}$ axles.

3. Calculate arrival times each axle using the distances and the constant velocity of vehicle.

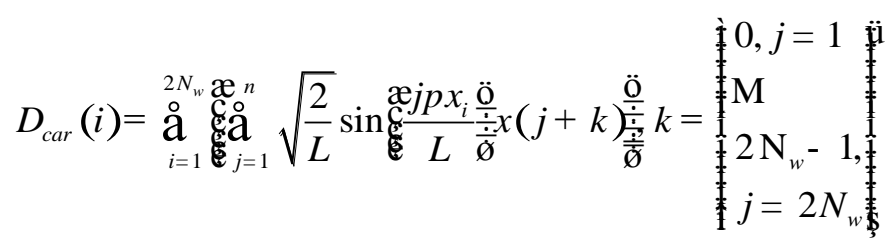




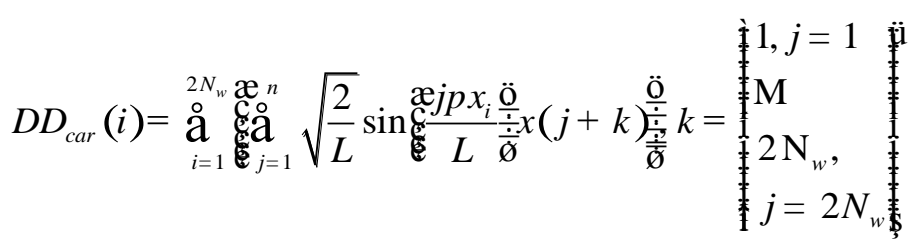

4. For axles, calculate equations (7) using above equations (6a and 6b).

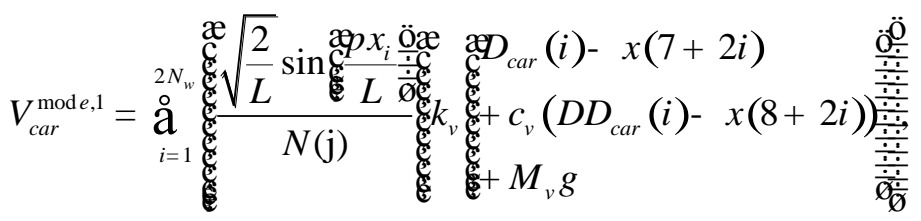

$\mathrm{M}$

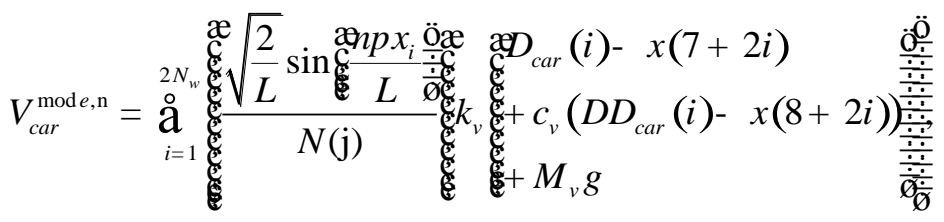

\section{Results}

In order to evaluate dynamics of the bridge for the case of multiple vehicle passage a simplified model of the case is given in Fig. 18 for $N_{w}$ cars. Each car has been modelled as separate 2 DOFtwo axle system with the parameters given in Table 1 . Where, $M_{v}=1000 \mathrm{~kg}$ is the half of the total mass of the car, $M_{w}=100 \mathrm{~kg}$ and suspension parameters spring and damping coefficients are $k_{v}=65$ $\mathrm{kN} / \mathrm{m}, c_{v}=1.5 \mathrm{kNm} / \mathrm{s}$ respectively. Additionally, a two new parameter for successive cars on the bridge as $N_{w}$ are $d_{w}$ are for the number of the cars and the distance between successive cars, respectively.

Fig. 2 shows an analyse result of midpoint response of the bridge for different number of cars $\left(N_{w}=2,4,6\right)$ with constant $d_{w}=3 \mathrm{~m}$ and constant velocity of $25 \mathrm{~m} / \mathrm{s}$. Also, Fig. 3 shows the effect of different $d_{w}$ for the range of 4-10 m. As can be seen from Figs. 2 and 3, increase of car number and decrease of distance between successive cars increases the midpoint response of the bridge. But in Fig. 3, high car numbers do not affect the response because the number of the cars is limited by the length of the bridge. However, the mass, suspension parameters and velocities of the cars are random in reality of the application. For an example of random loadings of the cars Fig. 4 shows the effect of some random parameters of vehicle as velocity $90 \leq v \leq 120 \mathrm{~km} / \mathrm{h}$, number of the cars up to $N_{w}=40$, spring coefficients of suspension $50 \leq K_{v} \leq 100 \mathrm{kN} / \mathrm{m}$, damping coefficient $1000 \leq C_{v} \leq 2500$ $\mathrm{Ns} / \mathrm{m}$, vehicle mass $750 \leq M_{v} \leq 1500 \mathrm{~kg}$, and distance $8 \leq d_{w} \leq 20 \mathrm{~m}$; are chosen randomly. 


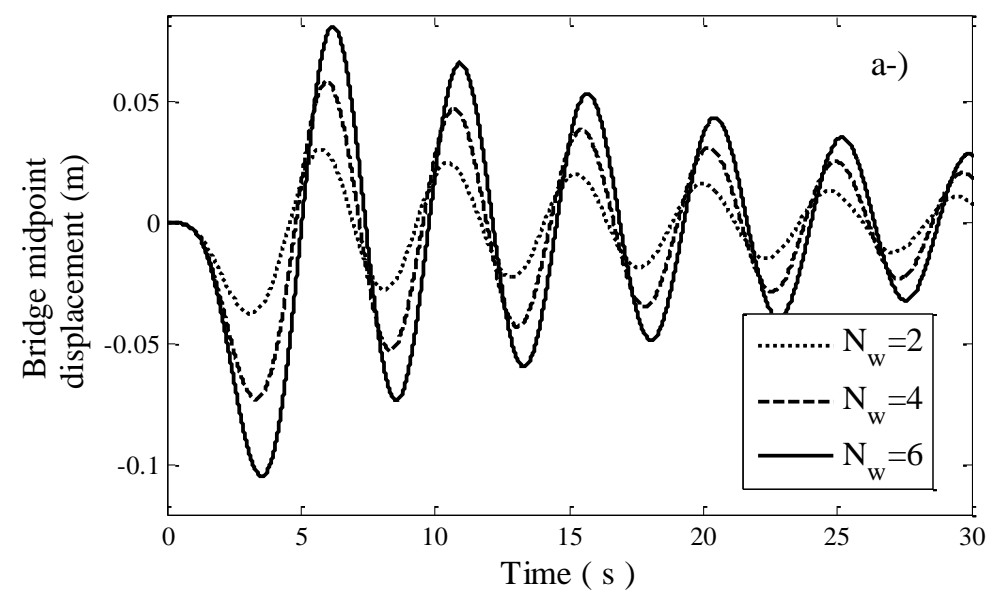

Fig. 2. Effect of number of vehicle moving on the bridge upon bridge midpoint maximum displacement.

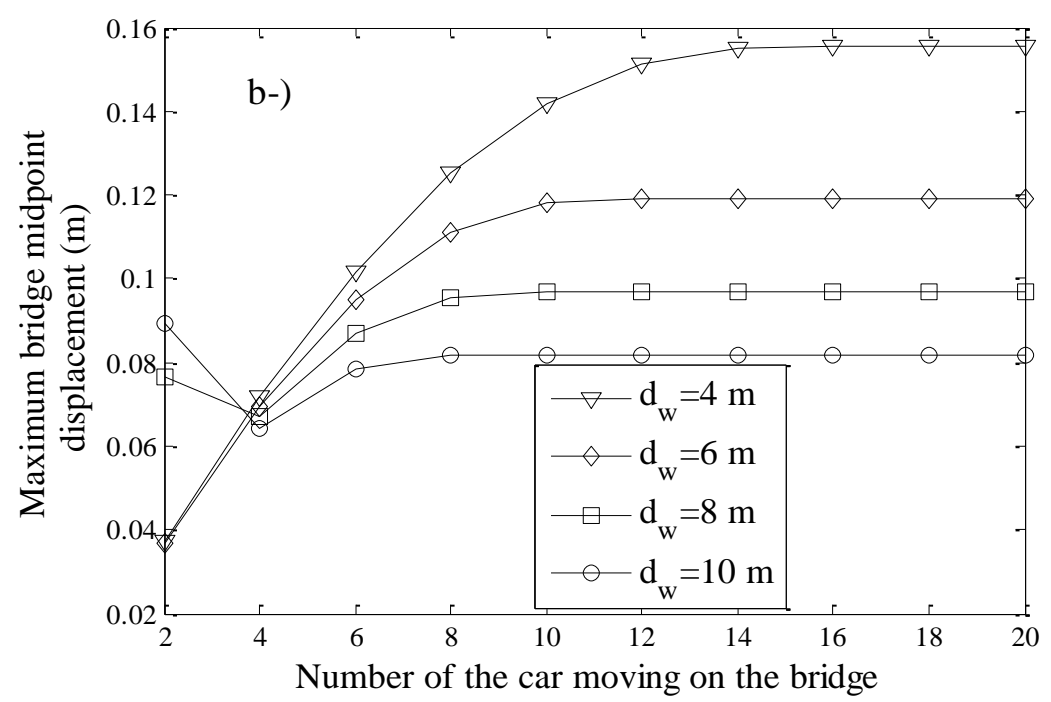

Fig. 3. Effect of number of vehicle moving on the bridge upon bridge midpoint maximum displacement.

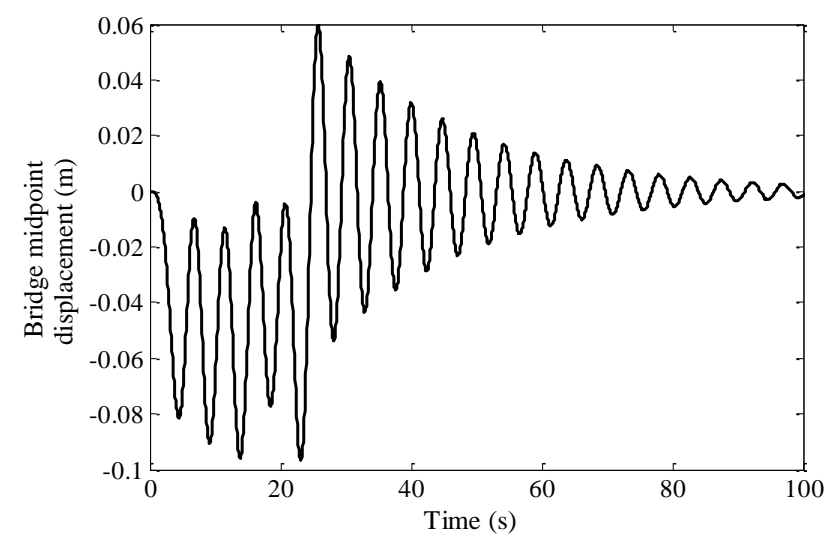

Fig. 4. Multiple vehicle and bridge interaction model used in this study. 


\section{Results and Discussion}

Multi-vehicle passing through flexible structure affects both bridge dynamics and vehicle dynamics. Increasing the number of vehicles passing through the bridge increases vehicle and bridge acceleration and displacements. In addition, the distance between vehicles affects vehicle and bridge vibrations

\section{References}

[1] L. Fryba, Vibration solids and structures under moving loads, Thomas Telford House, 1999.

[2] B. Dyniewicz, C.I. Bajer, New Consistent Numerical Modelling of a Travelling Accelerating Concentrated Mass, World J. Mech. 2 (2012) 281-287. doi:10.4236/wjm.2012.26034.

[3] H.P. Lee, Transverse vibration of a Timoshenko beam acted on by an accelerating mass, Appl. Acoust. 47 (1996) 319-330. doi:10.1016/0003-682X(95)00067-J.

[4] İ. Esen, A new FEM procedure for transverse and longitudinal vibration analysis of thin rectangular plates subjected to a variable velocity moving load along an arbitrary trajectory, Lat. Am. J. Solids Struct. 12 (2015) 808-830.

[5] İ. Esen, M.A. Koç, Dynamics of $35 \mathrm{~mm}$ anti-aircraft cannon barrel durig firing, in: Int. Symp. Comput. Sci. Eng., Aydın, 2013: pp. 252-257.

[6] M. Fafard, M. Bennur, M. Savard, A general multi-axle vehicle model to study the bridgevehicle interaction, Eng. Comput. 14 (1997) 491-508. doi:10.1108/02644409710170339.

[7] G. Michaltsos, D. Sophianopoulos, A.N. Kounadis, The Effect of a Moving Mass and Other Parameters on the Dynamic Response of a Simply Supported Beam, J. Sound Vib. 191 (1996) 357-362. doi:10.1006/jsvi.1996.0127.

[8] K. Youcef, T. Sabiha, D. El Mostafa, D. Ali, M. Bachir, Dynamic analysis of train-bridge system and riding comfort of trains, J. Mech. Sci. Technol. 27 (2013) 951-962. doi:10.1007/s12206-013-0206-8.

[9] Y.B. Yang, M.C. Cheng, K.C. Chang, Frequency Variation in Vehicle-Bridge Interaction Systems, Int. J. Struct. Stab. Dyn. 13 (2013) 1350019. doi:10.1142/S0219455413500193.

[10]H. Azimi, K. Galal, O.A. Pekau, A numerical element for vehicle-bridge interaction analysis of vehicles experiencing sudden deceleration, Eng. Struct. 49 (2013) 792-805. doi:10.1016/j.engstruct.2012.12.031.

[11]J. Wyss, D. Su, Y. Fujino, Prediction of vehicle-induced local responses and application to a skewed girder bridge, 33 (2011) 1088-1097. doi:10.1016/j.engstruct.2010.12.020.

[12]B. Liu, Y. Wang, P. Hu, Q. Yuan, Impact coefficient and reliability of mid-span continuous beam bridge under action of extra heavy vehicle with low speed, J. Cent. South Univ. 22 (2015) 1510-1520. doi:10.1007/s11771-015-2668-6.

[13]E. Esmailzadeh, N. Jalili, Vehicle-passenger-structure interaction of uniform bridges traversed by moving vehicles, J. Sound Vib. 260 (2003) 611-635. doi:10.1016/S0022-460X(02)00960-4.

[14]P. Lou, A vehicle-track-bridge interaction element considering vehicle's pitching effect, Finite Elem. Anal. Des. 41 (2005) 397-427. doi:10.1016/j.finel.2004.07.004. 